\title{
Deterrents and Detention: An Ill Conceived Afterthought
}

\author{
By William Angus and James Hathaway
}

This is abridged from an article which originally appeared in

The Globe and Mail, 25 August, 1987. Reprinted by permission.

In response to the clandestine arrival in Nova Scotia earlier this summer of 174 persons who subsequently claimed refugee status, the Federal Government recalled Parliament two weeks ago to introduce Bill C-84. Styled the Deterrents and Detention Bill, its content is every bit as ominous as its title suggests.

Although one of the Bill's purposes is stated to be to preserve access for genuine refugees, clearly the opposite result is achieved by some of its provisions. In an attempt to prevent abuse of the refugee determination system and to respond to security concerns, the proposed legislation has been drafted in such sweeping language that a number of its clauses are in fairly obvious violation of both international law and the Canadian Charter of Rights and Freedoms.

Simply put, the Bill goes too far. In its haste to respond to a perceived crisis, the Government has failed to respect fundamental legal standards.

\section{Determination Procedures}

No one disputes the propriety of affording protection to genuine refugees in fear of persecution. How to determine who is a genuine refugee and who is a false claimant, however, has been a vexing problem. From its inception under the new Immigration Act in 1978, the refugee determination process has been too slow and complex, with the result that genuine refugees are adversely prejudiced while false claimants abuse the process in the hope of gaining landed immigrant status by one means or another.

After numerous studies and a backlog of claims, Parliament now has new refugee claim procedures before it in Bill C-55. Although many of Bill C-55's provisions are controversial, its passage in a substantially amended form should resolve the pressing concerns associated with determining who is a genuine Convention refugee in a timely fashion. However, Bill C84 has suddenly emerged as a hastily arranged and ill conceived afterthought which would effectively preclude access to a fair and efficient determination process.

\section{Turning Away of Ships}

The proposed scheme would permit the Minister of Employment and Immigration forcibly to turn away ships that are in or approaching Canadian waters if he reasonably believes them to have unauthorized entrants aboard, including refugee claimants. This provision brings back shameful memories of Canada's decision in 1939 to turn away the ship St. Louis with its cargo of around 1,000 Jewish refugees, most of whom were forced back to Europe and Hitler's gas chambers. It is a needlessly arbitrary provision which violates international law, and which will not stop the smugglers' traffic in human suffering.

As the United Nations has pointed out to the Canadian Government, there is one fundamental obligation under internation al refugee law that can never be suspended, never be watered down, never be overlooked. That obligation is to hear the claims of persons who arrive at our borders that they would be persecuted if returned to their country of origin. One hundred nations, including Canada, have agreed that if a person can show that she or he faces the prospect of persecution on the ground of race, religion, nationality, social group, or political opinion, that person should be protected from return to his or her country of origin.

The problem with Bill C-84 is that it effectively guts this most basic international obligation by allowing the Minister, acting alone, to decide that a ship should be forced back out to the open seas without anyone on board having been given the chance to show why he or she deserves to be protected as a refugee by Canada. Not all claimants will be genuine refugees international law requires only that those who truly fear persecution be sheltered. If a hearing shows some or all passengers to be abusers or queue-jumpers, they can and should be sent away. Bill C-84, however, would make it impossible to sort out the real refugees from the bogus claimants, and would thus put Canada in breach of international law.

Nor will the turning back of ships stop the problem of smuggling refugee claimants. The owner and captain of the ships receive payment from their passengers up front, and will thus profit whether or not the refugee claimants make it to Canada. Desperate people will continue to be willing to take even a slim chance of reaching freedom. The real risk is that the would-be refugees may be dumped at sea by the frustrated crews of boats that are forced away by Canadian destroyers.

Hear the claims to refugee status quickly yet fairly, protect those who genuinely have reason to fear persecution, and send the abusers away.

\section{Arbitrary Detention}

Bill C-84 would introduce detention in situations of questionable identity or suspected security risk. After detention of a person for 7 days by a senior immigration officer, the Minister may issue a certificate without any explanation or justification, requiring detention for a further 21 days. Thereafter, an adjudicator may order the person detained for successive 7 day periods indefinitely.

Particularly offensive in Bill C-84 is the 21 day period of detention under a Minister's certificate, which is not challengeable before an adjudicator. It will undoubtedly provoke many habeus corpus attacks based on Charter arguments. Under section 9 of the Charter, one has the right not to be arbitrarily detained, while section 10 guarantees certain basic rights for everyone detained. Deprivation of personal liberty by the Minister or an immigration officer beholden to the Minister effectively denies the type of independent assessment which could - and should — be provided by a judge.

Continued on page 9 


\section{Continued from page 8}

\section{Prosecuting the Good Samari- tans}

Understandably Bill C-84 seeks to penalize the persons who are at the root of the problem of illicit immigration: the smugglers, the unscrupulous consultants, the various middlemen who profit by the abuse of Canadian immigration laws. Unfortunately, though, the Bill as drafted would permit the persons who have organized most of the recent bogus refugee movements to Canada to evade prosecution. On the other hand, its language is so broad as to criminalize persons whose work is generally viewed as humanitarian, not abusive.

Large scale movements of economic migrants posing as refugees are offensive, unfair, and should be stopped. This end could be attained by specifically prosecuting all persons who organize or assist persons to make fraudulent refugee claims in Canada. Rather than making it a criminal act to aid the perpetration of a fraud, however, the Government has instead chosen in Bill C-84 simply to make it illegal to assist the entry into Canada of persons without a valid visa. This vague approach leads to two kinds of problems.

First, the largest refugee hoaxes to date those involving the Portuguese, Turks, and Brazilians - would not have been stopped by the proposed law. All of those economic migrants either had valid visas, or arrived from countries which were not subject to a visa requirement. Organizers of these scams would therefore be acting within the scope of the proposed law, and could not be prosecuted. Because the proposal focuses on an irrelevant criterion - the failure to secure a visa, rather than on the real issue of concern - abuse and fraud by economic migrants, it fails to punish the persons who are the real wrongdoers.

Second, and more objectionable, the law would criminalize the work of church and other humanitarian agencies which assist undocumented refugess to apply for status under Canadian law. Most genuine refugees - those for whom persecution is imminent - simply cannot wait in their country of origin while a Canadian consulate processes an application for landing. They fear for their freedom and often their lives, and realize that they must escape at any price. True refugees are thus often compelled to escape surreptitiously, using false passports and travelling by unconventional means and routes.

A variety of Canadian humanitarian organizations has played the invaluable role of assisting genuine refugees to enter Canada, and to apply for recognition under our law. In Bill C-84, such persons motivated by strictly moral or humane concerns without remuneration of any kind can be fined up to $\$ 10,000$, imprisoned for five years, or both. By failing to distinguish between the crass and self-interested motives of smugglers on the one hand, and the commitment of many Canadian groups to assist the persecuted on the other, the Government has engaged in a form of legislative overkill. Even though these charitable organizations and individuals would not have engaged in any form of fraudulent activity, and indeed would have sought to assist refugees to comply with Canadian law, they face persecution under the provisions of Bill C-84.

\section{Search and Seizure}

Again as with arbitrary detention, the law and courts historically have been vigilant to protect individual rights relating to search and seizure by officialdom. Section 8 of the Charter expressly provides that everyone has the right to be secure against unreasonable search or seizure.

Bill C-84 contains far reaching search and seizure provisions which go well beyond comparable authority in the criminal law field. In some circumstances, an immigration officer would not even be required to obtain a search warrant. Bill C-84 permits an immigration officer to "break open any door, window, lock, fastener, floor, wall, ceiling, compartment, plumbing fixture, box, container or any other thing" for the purpose of carrying out a search or seizure. If a person challenges the seizure, it is the Minister who initially decides the issue, despite an obvious stake in the result where his departmental officials may have acted wrongly.

Clearly the search and seizure provisions of Bill C-84 need to be subjected to reasonable limitations if they are to survive Charter challenges and be consonant with respect for individual rights.

\section{It Goes Too Far}

Bill C-84 is a misguided and uninformed response to the legitimate concern of Canadians to ensure that only genuine refugees are protected by Canada. Yes, abuse should be deterred. But abuse can be deterred without violating international law, without infringing our Charter of Rights and Freedoms, and without making a mockery of our strong commitment to respect for human rights.

The authors are professors at the Osgoode Hall Law School who specialize in the field of immigration and refugee law.

\section{ACQUISITION AND NETWORKING:}

The Refugee Documentation Project (RDP) has co-signed with York University, a contract for the acquisition of UNESCO's sophisticated data base software, CDS/ISIS. The software is currently being adapted for downloading of RDP's data base. RDP is cooperating with the International Network of Researchers in the development of a mutually accessible system of exchange of machine-readable data. We are now equipped with international network facilities through BITNET. Mail may be sent to us by directing it to REFUGEE YYORK VM1 on BITNET. We welcome messages which will aid us in developing a global directory.

\section{NEW PUBLICATION:}

Oxford University Press, in association with the Refugee Studies Programme, University of Oxford, will commence publication of the JOURNAL OF REFUGEE STUDIES March 1988. Subscription rates for Volume One and further information are available from the Refugee Studies Programme, Queen Elizabeth House, University of Oxford, 21, St Giles, Oxford, OX1 3LA, U.K. Please note that this announcements is also a first call for papers. 